\title{
Intercropping of Grain and Fodder Maize Crops under Different Nitrogen Levels and Cutting Dates
}

\author{
Ahmed M. Shaalan; ${ }^{1}$ Hassan E. Khalil ${ }^{2}$; Ali I. Nawar ${ }^{3}$ and Mohamed M. El-salamouni ${ }^{4}$
}

\begin{abstract}
Two field experiments were conducted in 2013 and 2014 summer seasons, at the Experimental Research Station, Alexandria University, Egypt, to investigate the response of grain maize and fodder maize crops grown in associations to three $\mathrm{N}$ levels; i.e, 252 (N1), 288 (N2) and 324 (N3) $\mathrm{kg} \mathrm{N} / \mathrm{ha}$ and three cutting dates; i.e., $\mathrm{Cl}=(45)$, $\mathrm{C} 2=(60)$ and $\mathrm{C} 3=(75)$ days after sowing (DAS). The most important results are summarized as follows: 1) The two studied factors significantly affected plant height, ear leaf area, ear weight, 100-grain weight, grain yield and harvest index for grain maize, as well as green fodder yield/ha and percent of dry matter in fresh fodder in both seasons. 2) Each crop gave the highest and lowest values for its characters when they received, respectively, N3 and N1 levels, as well as at 75 and $45 \mathrm{DAS}$ periods of association. 3) The highest NUE of the intercrops to that of pure maize (RNUE) was obtained with the highest $N$ level over the two seasons. 4) The highest values of dry matter equivalent ratio (DMER) amounted to 1.23 and 1.26 (for N3), while, the lowest ones were 0.99 and 1.00 (for N1 level), corresponding to 1.25 and 1.29 for (C3), as well as, 1.09 and 1.10 for (C1) in 2013 and 2014 seasons, respectively.
\end{abstract}

Keywords: Intercropping, grain maize, fodder maize, nitrogen levels and cutting dates.

\section{INTRODUCTION}

Intercropping is a suitable strategy to increase crop productivity (Awal et al., 2006). It can ensure substantial yield advantages, as compared to sole cropping (Khalil and Nawar, 2004). Crop compatibility is the most essential factor for a practical intercropping system. Thus, the success of any intercropping system depends upon the proper choice of crops that produce a minimum competition between intercrops. By manipulation of the agriculture practices, there could be a reduced competition among plants. When there would be differences in growth periods between the principal crop and the subordinate one, yield advantage may increase with the length of these periods.

Maize is one of the main cereal summer crops in Egypt and its plants may be used as a source of fodder for animal feed since Egyptian maize hybrids remain green after ear harvesting. However, in different Egyptian region, maize is grown directly as a fodder crop (darawah). This is a short season (one-cut) fodder crop grown in the summer to provide for the needs of animal feed at the expense of grain maize area. To avoid that reduction in grain maize area, fodder maize may be intercropped with grain maize in additive model, in which the overall population density is larger than it is in the monocultures. Accordingly, maintaining the area of grain maize and obtaining an additional fodder maize from the same unit, avoiding grain yield reduction and reducing competition, caused by weeds. Researches reports, regarding fodder maize/grain maize intercropping are scarce, however, this investigation presents the first trial regarding this research point in Egypt.

Willey and Natarajan (1980), Francis (1986), Khalil and Nawar (2004) and Shaalan et al. (2014) pointed out that the production efficiency in cereal/legume intercrop systems could be improved when competition between component crops arrive at minimum values. In contrast, when the intercrops are similar in growth habits and overlap in their growth duration, there is less yield advantage than those of different growth habits (Midmore, 1993). The quality and quantity of fodder maize will depend on the plant age at cutting that affects recovery of grain maize from competition with fodder maize. Shorter association period between the two crops would be associated with greater recovery and uptake of available growth resources by grain maize to ensure higher grain yield (Fukai and Trenbath, 1993).

Different studies, related to maize response to nitrogen, were reported by Nawar (2004), Nawar et al. (2009) and Shaalan et al. (2014) who showed that N supply to maize increased plant height and the expansion of ear leaf. Similarly, Ali et al. (1999), and Khalil et al. (2011) attributed the increase in maize grain yield to enhancement of grain yield attributes as a result of increasing $\mathrm{N}$ level. Fodder maize (quality and quantity) is greatly responsive to $\mathrm{N}$ application.

\footnotetext{
${ }^{1}$ Faculty of Desert and Environmental Agriculture, Alexandria University, Matrouh Branch, Egypt.

${ }^{2}$ Crop Intensification Dep., Field Crop Research Institute, Agriculture Research Center (ARC), Giza, Egypt

${ }^{3}$ Crop Science Dep., Faculty of Agriculture, El- Shatby, Alexandria University, Egypt.

${ }^{4}$ Intertek Company for Cargo Inspection, Alexandria, Egypt.

Received November 3, 2015, Accepted December 16, 2015
} 
Increases in $\mathrm{N}$ level increase the amount and quality of fodder maize (Hassan et al. 2008)

This investigation was conducted to determine the effect of additive intercropping of maize for grain and fodder maize on their productivity under the combined effect of different cutting periods of fodder maize and different nitrogen levels.

\section{MATERIALS AND METHODS}

A two-year field study was conducted in 2013 and 2014 summer seasons at the Experimental Research Station, Alexandria University, Alexandria, Egypt, to investigate the response of maize (three-way cross, Giza 310) and fodder maize (darawah, house-hold seeds), gown in association, to three $\mathrm{N}$ levels $(\mathrm{N} 1=252$, $\mathrm{N} 2=288$ and $\mathrm{N} 3=324 \mathrm{~kg} \mathrm{~N} / \mathrm{ha}$ ) and the three cutting dates of fodder at $45(\mathrm{C} 1), 60(\mathrm{C} 2)$ and 75 (C3) days after sowing (DAS). Soil chemical properties were $\mathrm{PH}=$ 8.1 , organic matter $(\%)=0.016$ and available phosphorus (inorganic, $\mathrm{ppm}$ ) $=2.70$, total nitrogen $=$ $0.35 \%$ as an average of the two seasons.

Grain and fodder maize crops were simultaneously grown on May $15^{\text {th }}$ and $20^{\text {th }}$ in the two successive seasons, on alternate sides of ridges at one plant/hill (spaced at $25 \mathrm{~cm}$ apart) for grain maize $(100 \%$ plant population) and drilling at $48 \mathrm{Kg} / \mathrm{ha}$ seeding rate for fodder maize (1/3 of commercial seeding rate). A split plot design, with three replicates, was used, where the nitrogen levels occupied the main plots and the intercropping periods were allocated to the sub-plots. Each sub plot comprised five ridges, $3 \mathrm{~m}$ long and 0.7 $\mathrm{m}$ wide. Nitrogen levels, as ammonium nitrate $(33.5 \%$ $\mathrm{N})$, were applied in four doses, as follows: The first dose (72 kg N/ha) was applied at sowing and the remaining quantities of $\mathrm{N}$ were applied at subsequent doses at three 20-day intervals for all $\mathrm{N}$ levels. Other cultural practices were uniformly applied, according to recommendations.

Plants of the inner three ridges were harvested at soil surface to calculate fodder-plant height $(\mathrm{PH})$ and percentage of dry matter (as an average of five plants, taken at random from each sub-plot) and green fodder yield. Dry weight of forage was calculated from an oven-dried sample at $70{ }^{\circ} \mathrm{C}$ till a constant weight. Plant height $(\mathrm{cm})$ and ear leaf area $\left(\mathrm{cm}^{2}\right)$ of grain maize were recorded as the average of ten guarded plants, taken at random from each sub-plot. A sample of five ears were randomly taken from each sub-plot to calculate ear grain weight $(\mathrm{g})$. One-hundred grain weight $(\mathrm{g})$ was calculated as the average of three random samples, taken from each sub-plot. Grain yield was calculated from the three inner ridges of each sub-plot, then, converted to ton/ha.
Expressions of intercropping benefits were calculated, in terms of dry matter gain or loss (according to Andrews and Kassam, 1976) and dry matter equivalent ratio (DMER). NUE was calculated in simple terms as a ratio of output (total dry matter) to inputs (nitrogen units), Crop Science Society of America, 1992. In this investigation, the authors, also, proposed the concept of the dry matter equivalent ratio (DMER) as an index of additive intercropping yield advantage, where it was defined as the total dry matter of intercropped grain and fodder maize relative to pure grain maize dry matter, as follows:

Dry matter of intercrop grain maize + dry matter of fodder

\section{$\mathrm{DMER}=\quad$ Dry matter of pure grain maize}

When DMER $\leq 1$, there is no advantage to intercropping, in comparison with pure crop, however, when, it is $>1$, there is intercropping yield advantage.

Analysis of variance for each crop was separately applied according to Gomez and Gomez (1984), using SAS program, version 8.0.

\section{RESULTS AND DISCUSSION}

\section{1- Response of grain maize traits to different $N$ levels:}

The analysis of data, presented in Tables (1 and 2), indicated significant effects for $\mathrm{N}$ levels on all studied characters, except for ear height in both seasons. Differences, in plant height, of grain maize plants, among the three $\mathrm{N}$ levels, were significant, and were higher for grain maize supplied with $324 \mathrm{Kg} \mathrm{N} / \mathrm{ha}$ (N3), followed by $\mathrm{N} 2(288 \mathrm{~kg} \mathrm{~N} / \mathrm{ha})$, compared to the lowest $\mathrm{N}$ level of $252 \mathrm{Kg}$ N/ha (N1). Increasing the level of $\mathrm{N}$ increased $\mathrm{N}$ uptake, leading to greater vegetative growth, consequently, taller grain maize plants (ElGanbeehy et al., 2009 and Shaalan et al., 2014). Means for plant height, as affected by $\mathrm{N}$ application, indicated that $\mathrm{N} 3$ produced 6.35 and $14.38 \mathrm{~cm}$ (averaged over the two seasons) higher than that of N2 and N1 levels, respectively.

Ear leaf area response to nitrogen was proportional to the level of $\mathrm{N}$ applied. The greater the $\mathrm{N}$ level, the higher the ear leaf area was obtained, and that might be attributed to the enhancing effect of $\mathrm{N}$ on cell division, in addition to increase in leaf length and width dimensions (Andrade et al., 1999; Nawar, 2004 and Shaalan et al., 2014). On the average of the two seasons, increases in ear leaf area amounted to 19.69 and $57.68 \mathrm{~cm}^{2}$ for $324 \mathrm{Kg} \mathrm{N} /$ ha, relative to 288 and 252 $\mathrm{Kg} \mathrm{N} /$ ha, respectively.

Regarding ear weight, the highest value was obtained by application of $324 \mathrm{Kg} \mathrm{N} / \mathrm{ha}$. Increases in such trait were 43.5 and $27.2 \mathrm{~g}$, in the first season, corresponding to 49.52 and $27.85 \mathrm{~g}$, in the second 
season, for N3, compared to N1 and N2, respectively. These results agreed with those obtained by Subedi et al. (2006), Khalil et al. (2011) and Shaalan et al. (2014) who found that the increase in ear grain weight was in direct proportion with the increase in $\mathrm{N}$ application rate. Similarly, Nawar et al. (2009) attributed the increase in ear weight of maize to increases in grain number and photoassimilates translocation into ears as $\mathrm{N}$ level increased.

Response of 100-grain weight to $\mathrm{N}$ level was significant in the two seasons. Data showed that the heaviest weight was obtained by the N3 rate, which gave increases of 0.46 and $4.0 \mathrm{~g}$ (in the first season), corresponding to 1.4 and $4.9 \mathrm{~g}$ (in the second season), compared to $\mathrm{N} 2$ and $\mathrm{N} 1$, respectively. Increasing $\mathrm{N}$ level enhances $\mathrm{N}$ uptake, which results in the increase in leaf area index (LAI), light capture and conversion of growth resources into photoassimilates, which are translocated to the ears, hence increase grain weight (Grardner et al., 1985 and Zamski and Schaffer, 1996).

Application of nitrogen up to $324 \mathrm{Kg} \mathrm{N} / \mathrm{ha}$, significantly increased grain yield/ha. The highest yield was obtained from application of $324 \mathrm{~kg} \mathrm{~N} / \mathrm{ha}$ and surpassed the lowest and intermediate levels by 2.31 and 1.50 ton/ha, as an average of the two seasons, respectively. Lesser $\mathrm{N}$ uptake during grains development and maturity, as a result of applying lower $\mathrm{N}$ levels, might reduce photoassimilates production and translocation into developing grains, resulting in small and/or infertile grains and, in turn, resulting in lower grain yield (Uhart and Andrea 1995; Fageria 2009). These results were in agreement with those obtained by several investigators (Nawar, 2004, Khalil et al., 2011, Shaalan et al., 2014 and Ibrahim et al., 2015).

There was a significant response of harvest index (HI) to nitrogen application. Maximum and minimum values for such trait was obtained from N3 and N1, respectively. The $\mathrm{N} 3$ harvest index was, as an average of the two seasons, $36.9 \%$, compared to 32.61 and 32.7 $\%$, for N1 and N2, respectively. Higher N uptakes, with increasing $\mathrm{N}$ levels, enhance photoassimilates production and translocation of a higher proportion into economic grain yield relative to straw yield (Sinclair and Gardner, 1998, Shaalan et al., 2014 and Ibrahim et al., 2015). That may be explained by the transition of plants to the reproductive stage, where vegetative growth ceases and growth resources, including $\mathrm{N}$, are directed towards grain filling (Fageria, 2009).

Table 1. Means of studied characters, as affected by nitrogen levels and fodder cutting dates in 2013 summer season

\begin{tabular}{|c|c|c|c|c|c|c|c|}
\hline $\begin{array}{l}\text { Treatmen } \\
t\end{array}$ & $\begin{array}{c}\mathrm{PH} \\
(\mathrm{cm})\end{array}$ & $\begin{array}{c}\text { Ear height } \\
(\mathrm{cm})\end{array}$ & $\begin{array}{c}\text { Ear leaf } \\
\text { area }\left(\mathrm{cm}^{2}\right)\end{array}$ & $\begin{array}{c}\text { Ear weight } \\
\text { (g) }\end{array}$ & $\begin{array}{l}\text { 100-grain } \\
\text { weight (g) }\end{array}$ & $\begin{array}{c}\text { Grain } \\
\text { yield (t/ha) }\end{array}$ & $\begin{array}{l}\text { HI } \\
(\%)\end{array}$ \\
\hline \multicolumn{8}{|c|}{ Nitrogen levels: } \\
\hline $\mathrm{N} 1=252$ & $283.3 \mathrm{c}$ & $148.8 \mathrm{a}$ & $511.05 \mathrm{c}$ & $240.0 \mathrm{bc}$ & $30.04 \mathrm{bc}$ & $7.06 \mathrm{c}$ & $31.80 \mathrm{bc}$ \\
\hline $\mathrm{N} 2=288$ & $291.4 \mathrm{~b}$ & $147.6 \mathrm{a}$ & $549.36 \mathrm{~b}$ & $256.3 \mathrm{ab}$ & $33.56 \mathrm{ab}$ & $7.86 \mathrm{~b}$ & $31.88 \mathrm{ab}$ \\
\hline $\mathrm{N} 3=324$ & $297.8 \mathrm{a}$ & $143.3 \mathrm{a}$ & $569.22 \mathrm{a}$ & $283.5 \mathrm{a}$ & $34.02 \mathrm{a}$ & $9.33 \mathrm{a}$ & $35.96 \mathrm{a}$ \\
\hline \multicolumn{8}{|c|}{ Cutting dates: } \\
\hline $\mathrm{C} 1=45$ & $280.3 \mathrm{c}$ & $144.1 \mathrm{a}$ & $559.52 \mathrm{a}$ & $281.4 \mathrm{a}$ & $33.92 \mathrm{a}$ & $8.80 \mathrm{a}$ & $39.06 \mathrm{a}$ \\
\hline $\mathrm{C} 2=60$ & $293.2 \mathrm{~b}$ & $143.7 \mathrm{a}$ & $542.42 \mathrm{~b}$ & $260.6 \mathrm{ab}$ & $32.87 \mathrm{ab}$ & $8.14 \mathrm{~b}$ & $31.74 \mathrm{~b}$ \\
\hline $\mathrm{C} 3=75$ & $299.0 \mathrm{a}$ & $151.9 \mathrm{a}$ & $527.7 \mathrm{c}$ & $237.7 \mathrm{~b}$ & $31.59 \mathrm{bc}$ & $7.26 \mathrm{c}$ & $28.81 \mathrm{bc}$ \\
\hline
\end{tabular}

Means in the same column followed by the same letter (s) were not significantly at 0.05 level of probability.

Table 2. Means of studied characters, as affected by nitrogen levels and fodder cutting dates in 2014 summer season

\begin{tabular}{|c|c|c|c|c|c|c|c|}
\hline $\begin{array}{l}\text { Treatmen } \\
t\end{array}$ & $\begin{array}{c}\text { PH } \\
(\mathrm{cm})\end{array}$ & $\begin{array}{c}\text { Ear height } \\
(\mathrm{cm})\end{array}$ & $\begin{array}{c}\text { Ear leaf } \\
\text { area }\left(\mathrm{cm}^{2}\right)\end{array}$ & $\begin{array}{c}\text { Ear weight } \\
\text { (g) }\end{array}$ & $\begin{array}{l}\text { 100-grain } \\
\text { weight (g) }\end{array}$ & $\begin{array}{c}\text { Grain } \\
\text { yield (t/ha) }\end{array}$ & $\begin{array}{c}\text { HI } \\
(\%)\end{array}$ \\
\hline \multicolumn{8}{|c|}{ Nitrogen levels: } \\
\hline $\mathrm{N} 1=252$ & $278.82 \mathrm{c}$ & $146.44 \mathrm{a}$ & $502.87 \mathrm{c}$ & $242.52 \mathrm{bc}$ & $31.00 \mathrm{bc}$ & $7.22 \mathrm{c}$ & $33.42 \mathrm{bc}$ \\
\hline $\mathrm{N} 2=288$ & $286.78 \mathrm{~b}$ & $145.26 \mathrm{a}$ & $540.53 \mathrm{~b}$ & $264.19 \mathrm{ab}$ & $34.53 \mathrm{ab}$ & $8.04 \mathrm{~b}$ & $33.52 \mathrm{ab}$ \\
\hline $\mathrm{N} 3=324$ & $293.07 \mathrm{a}$ & $141.03 \mathrm{a}$ & $560.05 \mathrm{a}$ & $292.04 \mathrm{a}$ & $35.90 \mathrm{a}$ & $9.56 \mathrm{a}$ & $37.83 \mathrm{a}$ \\
\hline \multicolumn{8}{|c|}{ Cutting dates: } \\
\hline $\mathrm{C} 1=45$ & $275.87 \mathrm{c}$ & $141.82 \mathrm{a}$ & $550.51 \mathrm{a}$ & $287.69 \mathrm{a}$ & $35.00 \mathrm{a}$ & $9.01 \mathrm{a}$ & $39.60 \mathrm{a}$ \\
\hline $\mathrm{C} 2=60$ & $288.55 \mathrm{~b}$ & $141.43 \mathrm{a}$ & $533.70 \mathrm{~b}$ & $268.42 \mathrm{ab}$ & $33.82 \mathrm{ab}$ & $8.34 \mathrm{~b}$ & $33.43 \mathrm{~b}$ \\
\hline $\mathrm{C} 3=75$ & $294.25 \mathrm{a}$ & $149.49 \mathrm{a}$ & $519.23 \mathrm{c}$ & $242.62 \mathrm{~b}$ & $32.60 \mathrm{bc}$ & $7.42 \mathrm{c}$ & $31.76 \mathrm{bc}$ \\
\hline
\end{tabular}

Means in the same column followed by the same letter (s) were not significant at 0.05 level of probability. 


\section{2- Response of grain maize traits to intercropping period with fodder maize:}

Means of the studied characters of grain maize, as affected by the association period with fodder maize, are presented in Tables (1 and 2). Data indicated that plant height of grain maize was significantly influenced by intercropping period with fodder maize. Increase in the number of days to cutting of fodder maize increased plant height over the two seasons. Heights of maize plants, when it was intercropped with fodder up to 75 DAS, were the tallest, while, the shortest at 45 DAS. Plant height, as an average of the two seasons, was 278.09 (for C1), 290.88 (for C2) and 296.63 (for C3). Increasing the association period to cutting, the association between grain and fodder maize, will increase the competition between the two crops, since both are similar in their growth habits and requirements in the vegetative stage. That would, of course, lead to taller plants, able to compete for light resource (Fukai and Trenbath, 1993).

There were significant variations in ear leaf area among all periods to cutting of fodder maize. The increase in that trait was indirectly proportional to the period length of cutting fodder maize over the two seasons. When maize was intercropped with fodder maize for 45 days, it produced wider ear leaf area by 17.10 and $31.82 \mathrm{~cm}^{2}$, in 2013 , corresponding to 16.81 and $31.28 \mathrm{~cm}^{2}$, in 2014 , compared to cutting at 60 and 75-days age, respectively. Lower competition for light in the shortest period of association, in addition to better recovery and utilization of soil nutrients for longer period after cutting (45 DAS), increased photoassimilates production and translocation into the vegetative parts, resulting in the greater expansion of ear leaf area (El-Ganbeehy et al., 2009).

Response of ear weight of maize to cutting after different periods was significant in both seasons. The trend of data revealed a decrease in ear weight with delaying cutting up to 75 DAS. That might be explained by the longer competition period between the intercrops for light and soil growth resources, leading to a reduction in ear leaf area and, consequently, lower assimilates production and translocation to the ear. The same trend of response, also, was recorded for 100grain weight, where increases in that character, as an average of the two seasons, for cutting period 45 DAS reached 2.37 and $1.12 \mathrm{~g}$ over 75 and 60 DAS cutting treatments, respectively. Similar findings were reported by Jacobs and Pearson (1990) and El-Ganbeehy et al. (2009).
With regard to grain yield/ha, it was significantly affected by different day-old plants at cutting in both seasons. Grain yield for $\mathrm{C} 1$ was superior to $\mathrm{C} 2$ and $\mathrm{C} 3$ treatments by 0.66 and 1.54 tons/ha (in the first season), corresponding to 0.67 and 1.59 ton/ha (in the second season), respectively. Shorter intercropping period allows grain maize to grow for a longer period free from intercompetition. Hence, it will have better growth resources utilization and higher photosynthesis potential resulting in better assimilates production and distribution to ears. That will lead to, as previously presented, higher ear and grain weight, which will, finally, increase grain yield (Blair et al., 2006 and Egli, 2008).

Concerning harvest index (HI) data showed that this trait had the same trend, as grain yield, in both seasons. Maximum and minimum values of maize harvest index were consequently, obtained from 45 and 75 DAS treatments. Superiority of (HI) in $\mathrm{C} 1$, compared to $\mathrm{C} 3$ and $\mathrm{C} 2$ might be attributed to higher increase in grain yield, compared to straw yield. These results were in accordance with those of Sinclair and Gardner (1998), Shaalan et al. (2014) and Ibrahim et al. (2015) who found that increase in plant economic component (grain yield), relative to uneconomic (straw yield), increased maize harvest index.

\section{3- The interaction between $\mathrm{N}$ levels and cutting dates:}

Interaction between the two studied factors was, only, significant for ear leaf area in the two seasons. Results presented in Table(3) indicated that the response of that character to $\mathrm{N}$ levels, under the same cutting date, showed different magnitudes, where the increase in ear leaf area, with increasing $\mathrm{N}$ level from $\mathrm{N} 1$ to $\mathrm{N} 2$ was higher than that from $\mathrm{N} 2$ to $\mathrm{N} 3$, as an average of both seasons. These values were 518.48, 559.93 and $586.64 \mathrm{~cm}^{2}$ at 45 DAS; $507.23,541.42$ and $565.54 \mathrm{~cm}^{2}$, at 60 DAS and $495.17,533.48$ and 541.72 $\mathrm{cm}^{2}$, at 75 DAS, as averages of both seasons. Hence, the highest ear leaf area $\left(586.65 \mathrm{~cm}^{2}\right)$ was obtained with the highest $\mathrm{N}$ level $(\mathrm{N} 3)$ and 45 DAS old, whereas, the lowest ear leaf area was recorded for the lowest $\mathrm{N}$ level (N1) at 75 DAS cutting date $\left(495.17 \mathrm{~cm}^{2}\right)$, as an average of the two seasons. The differences, in response of ear leaf area to the interaction of the two studied factors, may be attributed to the ability of the grain maize plants to recover from competition with fodder maize and better utilization of growth resources. That ability will be improved by shorter competition period and higher $\mathrm{N}$ level application (El-Ganbeehy et al.,2009 and Shaalan et al., 2014). 
Table 3. Ear leaf area of maize grain as affected by the interaction between $\mathbf{N}$ levels and cutting dates in 2013 and 2014 seasons

\begin{tabular}{lcccccc} 
Cutting dates & \multicolumn{3}{c}{$\mathbf{2 0 1 3}$ season } & \multicolumn{3}{c}{ 2014 season } \\
\cline { 3 - 7 } N-levels & $\mathbf{4 5}$ & $\mathbf{6 0}$ & $\mathbf{7 5}$ & $\mathbf{4 5}$ & $\mathbf{6 0}$ & $\mathbf{7 5}$ \\
\hline $\mathrm{N} 1=252$ & 522.52 & 512.38 & 498.26 & 514.44 & 502.09 & 492.08 \\
\hline $\mathrm{N} 2=288$ & 566.56 & 542.33 & 539.20 & 553.31 & 540.52 & 527.76 \\
\hline $\mathrm{N} 3=324$ & 589.48 & 572.55 & 45.64 & 583.81 & 558.53 & 537.81 \\
\hline $\mathrm{LSD} 0.05$ & \multicolumn{3}{c}{22.23} & & & 20.86 \\
\hline
\end{tabular}

4- Fodder maize productivity as affected by $\mathrm{N}$ levels and cutting periods:

Data in Table (4) showed that fodder fresh yield/ha and its dry matter, as dry weight percent, were significant in response to $\mathrm{N}$ level, where the increase in those traits were in proportion to the supply of $\mathrm{N}$ level during the two seasons. When the intercrop was supplied with $324 \mathrm{~kg} \mathrm{~N} / \mathrm{ha}$, fodder maize produced greater fresh weight by 0.68 and $4.80 \mathrm{t} / \mathrm{ha}$, as an average of the two seasons, for N3, compared to N2 and N1 levels, respectively. Furthermore, variations in dry weight (\%) (as percentage of fresh yield/ha) were, also, significant in response to $\mathrm{N}$ levels and had the same trend of fresh yield over the two seasons. Increasing $\mathrm{N}$ level up to $324 \mathrm{~kg} \mathrm{~N} /$ ha gave the highest values of that trait, compared to the lowest $\mathrm{N}$ level. These results were in accordance with those of Keshin (2005), El-Sarag and Abou Hashem (2009) Hassan et al. (2008) and Shahin et al. (2013) who found that increasing $\mathrm{N}$ level led to an increase in fresh and dry yields of the fodder crop and attributed these findings to the effect of $\mathrm{N}$ fertilization in enhancing plant growth due to the increase of photoassimilates production and translocation to the vegetative parts of plant.

Regarding the effect of intercropping period on fodder maize traits, data in Table (4) showed positive significant response of intercropped fodder maize to delay in cutting dates. Increasing the intercrops period increased the values of fodder. Plant height, fresh yield and dry matter, as a percentage of fodder fresh yield superiority of fodder height at $\mathrm{C} 3$ was greater than that obtained at $\mathrm{C} 2$ and $\mathrm{C} 1$, respectively, by 61.0 and 145.4 $\mathrm{cm}$, in the first season, and by 63.15 and $157.4 \mathrm{~cm}$ in the second seasons, respectively. Increase in period of association increased competition between grain and fodder maize for light, leading to greater vegetative growth and, consequently, taller fodder maize plants (Nawar, 2004).

Yield of green fodder performed the same trend as that of plant height over the two seasons. It was superior with delay in harvesting (C3), compared to $\mathrm{C} 2$ and $\mathrm{C} 1$, respectively, by 2.60 and $6.0 \mathrm{t} / \mathrm{ha}$, as an average of the two seasons. Lesser uptake of available $\mathrm{N}$ resource (C2) and $(\mathrm{C} 1)$, during vegetative growth, might reduce photoassimilates production and translocation into the plant green parts, resulting in lower yields from fodder maize. Dry matter percentage was significantly higher in $\mathrm{C} 3$, compared to that of $\mathrm{C} 2$ and $\mathrm{C} 1$ over the two seasons. The highest values for that trait was obtained from $\mathrm{C} 3$, however, the lowest ones were obtained from the intercrop for 45 cutting date.

Table 4. Plant height at cutting (cm), yield of green fodder (ton/ha) and dry weight \% as affected by $\mathrm{N}$ levels and cutting dates in 2013 and 2014 summer seasons

\begin{tabular}{ccccccc}
\hline \multirow{2}{*}{ Treatment } & $\begin{array}{c}\text { Plant height } \\
\text { at cutting } \\
\text { (cm) }\end{array}$ & $\begin{array}{c}\text { Yield of green } \\
\text { fodder } \\
\text { (ton/ha) }\end{array}$ & $\begin{array}{c}\text { dry weight } \\
\mathbf{( \% )}\end{array}$ & $\begin{array}{c}\text { Plant height } \\
\text { at cutting } \\
\text { (cm) }\end{array}$ & $\begin{array}{c}\text { Yield of green } \\
\text { fodder } \\
\text { (ton/ha) }\end{array}$ & $\begin{array}{c}\text { dry weight } \\
\text { (\%) }\end{array}$ \\
\hline Nitrogen levels (Kg N/ha): & & & & & \\
\hline N1=252 & $144.1 \mathrm{a}$ & $12.12 \mathrm{bc}$ & $27.77 \mathrm{bc}$ & $145.68 \mathrm{a}$ & $12.20 \mathrm{bc}$ & $29.24 \mathrm{bc}$ \\
\hline $\mathrm{N} 2=288$ & $153.7 \mathrm{a}$ & $15.99 \mathrm{ab}$ & $34.09 \mathrm{ab}$ & $163.99 \mathrm{a}$ & $16.57 \mathrm{ab}$ & $35.89 \mathrm{ab}$ \\
\hline $\mathrm{N} 3=324$ & $158.2 \mathrm{a}$ & $16.53 \mathrm{a}$ & $37.11 \mathrm{a}$ & $171.17 \mathrm{a}$ & $17.38 \mathrm{a}$ & $39.07 \mathrm{a}$ \\
\hline Cutting dates: & & & & & & \\
\hline $\mathrm{C} 1=45$ & $75.4 \mathrm{c}$ & $11.97 \mathrm{c}$ & $25.08 \mathrm{c}$ & $76.40 \mathrm{c}$ & $12.03 \mathrm{c}$ & $26.40 \mathrm{c}$ \\
\hline $\mathrm{C} 2=60$ & $159.8 \mathrm{~b}$ & $15.14 \mathrm{~b}$ & $30.61 \mathrm{~b}$ & $170.65 \mathrm{~b}$ & $15.65 \mathrm{~b}$ & $32.23 \mathrm{~b}$ \\
\hline $\mathrm{C} 3=75$ & $220.8 \mathrm{a}$ & $17.53 \mathrm{a}$ & $43.28 \mathrm{a}$ & $233.80 \mathrm{a}$ & $18.47 \mathrm{a}$ & $45.57 \mathrm{a}$ \\
\hline
\end{tabular}

Means in the same column followed by the same letter (s) were not significant at 0.05 level of probability. 
5- Efficiency evaluation of grain/fodder maize intercropping:

Both intercrops, grain maize and fodder maize, are essentially used for animal feed. Therefore, the dry matter content for each is the primary character to be taken in consideration when evaluating the productivity of intercrops per unit area. The authors proposed a measurement; i.e., dry matter equivalent ratio (DMER), to express the gain or loss in dry matter production per unit area under different $\mathrm{N}$ levels and cutting periods effect. That measurement includes the determination of total dry matter produced by intercrops (fodder maize + straw and grain yields of grain maize) relative to the dry matter production of pure grain maize.

Data presented in Table (5) indicated that increasing $\mathrm{N}$ application level increased DMER in the two seasons. Values for DMER reached 0.99, 1.19 and 1.23 for N1, $\mathrm{N} 2$ and N3 levels, in the first season, respectively. Corresponding values, in the second season, were 1.00, 1.21 and 1.26 , respectively. These data indicated that the lowest $\mathrm{N}$ level $(252 \mathrm{~kg} \mathrm{~N} / \mathrm{ha})$ showed no gain in dry matter production per unit area for intercrops, compared to pure maize. However, increasing $\mathrm{N}$ application level to 288 and $324 \mathrm{~kg} \mathrm{~N} / \mathrm{ha}$ was accompanied by an increase in dry matter production by 20 and $24.5 \%$, as an average of the two seasons, respectively. On the other hand, intercropping fodder maize into grain maize (additive intercropping) showed a progressive increase in dry matter production for the three cutting dates, 45 , 60 and 75 DAS, with an average DMER values, over the two seasons, of $1.05,1.12$ and 1.27 , respectively, compared to pure maize (value taken at recommended $\mathrm{N}$ level of $288 \mathrm{~kg} \mathrm{~N} / \mathrm{ha}$ ). These findings emphasize the dry matter productivity per unit area and, hence, increase the efficiency of land area for animal feed. Moreover, data presented in Table (5) revealed the superiority of intercropping, over pure maize, in nitrogen use efficiency especially at higher nitrogen application (324 kg N/ha) in both seasons. That, accompanied with higher dry matter production, emphasize the importance of intercropping as a simple and an effective method for increasing the efficient use of land and resources (nitrogen fertilization) in increasing dry matter production.

Table 5. Dry matter production, DMER and NUE for grain and fodder maize, as affected by $\mathrm{N}$ levels and cutting dates in 2013 and 2014 summer seasons

\begin{tabular}{|c|c|c|c|c|c|c|c|c|}
\hline $\begin{array}{l}\text { Treatmen } \\
\text { t }\end{array}$ & $\begin{array}{c}\text { Grain } \\
\text { yield } \\
\text { (Dry } \\
\text { matter) } \\
\text { (ton/ha } \\
\text { ) }\end{array}$ & $\begin{array}{c}\text { Straw } \\
\text { yield } \\
\text { (Dry } \\
\text { matter) } \\
\text { (ton/ha } \\
\text { ) }\end{array}$ & $\begin{array}{c}\text { Forage } \\
\text { (Dry } \\
\text { matter) } \\
\text { (ton/ha } \\
\text { ) }\end{array}$ & $\begin{array}{c}\text { Total dry } \\
\text { matter of } \\
\text { maize } \\
\text { (grain+ } \\
\text { fodder) } \\
\end{array}$ & $\begin{array}{c}\text { Total } \\
\text { dry } \\
\text { matter } \\
\text { pure } \\
\text { (ton/ha } \\
\text { ) }\end{array}$ & $\begin{array}{c}\text { Dry } \\
\text { matter } \\
\text { equivalen } \\
\text { t ratio } \\
\text { (DMER) }\end{array}$ & $\begin{array}{c}\begin{array}{c}\text { Nitrogen use } \\
\text { efficiency } \\
\text { (intercropping } \\
\text { ) }\end{array} \\
\end{array}$ & $\begin{array}{c}\text { Nitrogen } \\
\text { use } \\
\text { efficienc } \\
\text { y (pure) }\end{array}$ \\
\hline \multicolumn{9}{|c|}{2013 season } \\
\hline \multicolumn{9}{|c|}{ Nitrogen levels (kg N/ha) } \\
\hline $\mathrm{N} 1=252$ & 5.22 & 10.98 & 3.36 & 19.56 & 19.78 & 0.99 & 0.22 & 0.22 \\
\hline $\mathrm{N} 2=288$ & 5.81 & 12.9 & 5.45 & 24.16 & 20.37 & 1.19 & 0.23 & 0.19 \\
\hline $\mathrm{N} 3=324$ & 6.89 & 13.45 & 6.13 & 26.47 & 21.60 & 1.23 & 0.22 & 0.18 \\
\hline \multicolumn{9}{|c|}{ Cutting dates: } \\
\hline $\mathrm{C} 1=45$ & 6.50 & 12.79 & 3.00 & 22.29 & & 1.09 & & \\
\hline $\mathrm{C} 2=60$ & 6.02 & 12.08 & 4.63 & 22.73 & & 1.12 & & \\
\hline $\mathrm{C} 3=75$ & 5.36 & 12.49 & 7.58 & 25.43 & & 1.25 & & \\
\hline Pure maize & 6.97 & 13.53 & & 20.37 & & & & \\
\hline \multicolumn{9}{|c|}{2014 season } \\
\hline \multicolumn{9}{|c|}{ Nitrogen levels (kg N/ha) } \\
\hline $\mathrm{N} 1=252$ & 5.33 & 10.44 & 3.57 & 19.34 & 19.36 & 1.00 & 0.21 & 0.22 \\
\hline $\mathrm{N} 2=288$ & 5.94 & 12.27 & 5.95 & 24.16 & 20.00 & 1.21 & 0.23 & 0.19 \\
\hline $\mathrm{N} 3=324$ & 7.07 & 12.73 & 6.79 & 26.59 & 21.10 & 1.26 & 0.22 & 0.18 \\
\hline \multicolumn{9}{|c|}{ Cutting dates: } \\
\hline $\mathrm{C} 1=45$ & 6.66 & 12.12 & 3.18 & 21.96 & & 1.10 & & \\
\hline $\mathrm{C} 2=60$ & 6.16 & 11.46 & 5.04 & 22.66 & & 1.13 & & \\
\hline $\mathrm{C} 3=75$ & 5.48 & 11.90 & 8.42 & 25.80 & & 1.29 & & \\
\hline Pure maize & 7.10 & 13.05 & & 20.00 & & & & \\
\hline
\end{tabular}


These findings were in harmony with those reported by Tolera et al. (1998), Hamid and Nasab (2001) and Carpici et al. (2010) who concluded that both $\mathrm{N}$ level and cutting date were the primary factors affecting dry matter accumulation in forages and determining productivity of herbage. In addition, intercropping of fodder maize into grain maize may remedy the harmful practices performed by the Egyptian farmers, in grain maize production, such as delayed thinning, detopping and defoliation to provide green forage during summer.

\section{REFERENCES}

Ali, A.A., G.M.A. Mahgoub, and A.H. Awad. 1999. Response of white maize hybrid (Sc1) to nitrogen and different plant distributions .J. Agric. Sci, (26):151-161.

Andrade, F.H., C. Vega, S. Uhart, A. Cirilo, M. Cantarero and O. Valentinuz. 1999. Kernel number determination on maize. Crop Sci. (39): 543-549.

Andrews, D.J and A.H. Kassam. 1976. The importance of intercropping in increasing world food supplies. Multiple cropping, A.S.A, special publication, No 27:1-10.

Awal , M.A., H. Koshi and T. Iked. 2006. Radiation interception and use by maize/peanut intercrop. Agric. and Forest Meteor., (139):74-83.

Blair, N., R.D. Faulkner and P.R. Poulton. 2006. Long term management impacts on soil. C,N and Physical Fertility. Soil and Tillage Res., (91):30-39

Carpici, E. B., N. Celik and G. Bayram. 2010. Yield and quality of forage maize as influenced by plant density and nitrogen rate. Turkish J. of Field Crops., 15 (2): 128-132.

Crop Science Society of America. 1992. Glossary of Crop Science Terms. Madison, WI: Crop Sci. Soc. of America, USA.

Egli,D.B. 2008. Comparison of corn and soybean yields in the United States .Historical trends and future prospects. Agron. J., (100) :Suppl,79-88.

EL-Ganbeehy , M.M. , H.E. Khalil and A.S. Kamel. 2009. Maize for grain and fodder under different seeding rates and N levels Minufiya J. Agric. Res., (34):661-675.

EL-Sarag E. I. and G.M. Abou Hashem, 2009. Effect of irrigation intervals and nitrogen rates on forage sorghum under north Sinai conditions. Zagazig J. Agric. Res., (36):19-39.

Fageria, N.K. 2009. Nitrogen. pp. 31-90. In "The Use of Nutrients in Crop Plants". CRC press, Florida, USA.

Francis, C.A. 1986. Distribution and Importance of Multiple Cropping. P. 1-19. IN C.A. Francis (ed.) Multiple Cropping System. Macmillan Publishing Company, New York, USA.

Fukai S. and S. Trenbath. 1993. Intercropping basses of productivity. Field Crop Res., (34): 239-245.
Gardner, F.B., R.B. Peacre and R.L. Nit chell. 1985. Physiology of Crop Plants. Iowa State Univ. Press, Ames, Iowa, U.S.A.

Gomez, K.A. and A.A. Gomez. 1984. Statistical Procedures for Agriculture Research. $2^{\text {nd }}$ ed. John Wiley and Sons, New York, U.S.A.

Hamid, A. and A.D.M. Nasab. 2001. The effect of various plant densities and $\mathrm{N}$ levels on phenology of two medium maturity corn hybrids. Ind. J. Agric. Sci., (32): 857-874.

Hassan, Hend H.M., E.M. Zeidan, I.E. Ramadan and H.G. Geweifel. 2008. Effect of sowing date, planting density and nitrogen fertilization on forage yield and quality of fodder maize. Zagazig J. Agric. Res., (35): 1281-1299.

Ibrahim, H.M., T.I.E. Abd El-Wahab, A.I. Nawar and H.E. Khalil .2015. Maize response to different $\mathrm{N}$ levels following different preceding crops. Alex. Sci. Exch. J., (36): 214-220.

Jacobs, B.C. and C.J. Pearson. 1990. Potential yield of maize determined by rates of growth and development of ears. Field Crops Res., (27):281-298.

Keshin, B., H. Akdeniz, Y. Hakki, H. Ibrahim and N. Turan. 2005. Yield and quality of forage corn (zea mays L.) as influenced by cultivar and nitrogen rate. Journal of Agronomy 4 (2):138-141.

Khalil, H.E. and A.I Nawar. 2004. Productivity of maize and soybean association patterns after different winter crops. Minufiya J. Agric. Res. 29 (3): 679-693.

Khalil, H.E., A.I. Nawar, A.M. Abou-Ela, I.E. Mohammadein and M.E. El-Sodany. 2011. Response of maize to N fertilization and rotational crop sequences .Alex. J. Agric. Res.,(54):29-39.

Midmore, D.J. 1993. Agronomic modification of resource use and intercrop productivity. Field Crop Research (34): $357-$ 381.

Nawar, A.I. 2004. Nitrogen requirements for maize cultivars after different winter crops. J. Adv. Agric. Res., (9): 607621.

Nawar, A.I., I.E. Mohammadein and H.E. Khalil. 2009. Response of maize to $\mathrm{N}$ fertilization and rotational crop sequences. Alex. J. Agric. Res., (54): 29-39.

Shaalan, A.M., Nagwa A.R., A.S.A., Shams and H.E. Khalil. 2014. Rotational crop sequences and $\mathrm{N}$ fertilization levels effect on maize growth and productivity. Alex. Sci. Exch. J. (35): 154-161.

Shahin, M.G., R.Th. Abdorabou, W.R. Abdel Momen and Maha R.H. 2013. Response of growth and forage yield of pearl millet (Pennisetum galucum) to nitrogen fertilization rates and cutting height. Ann. Of. Agric. Sci., (58): 153163.

Sinclair, T.R. and E.P. Gardner. 1998. Environmental limits to Plant Production. Pp. 63-78. In "Principles of Ecology in Plant Production", CBA, New York, USA. 
Subedi, K.D., B.L. Ha and D.L. Smith. 2006. Response of leafy and non-leafy maize hybrids to population densities and Nitrogen levels fertilizer. Crop Sci. (46): 1860-1869.

Tolera, A., F. Sundstol and A. N. Said. 1998. The effect of stage of maturity on yield and quality of maize grain and stover. Animal Feed Sci. and Tech., 75 (2): 157-168.
Uhart, S.A. and F.H. Andrea. 1995. Nitrogen deficiency in maize. 1- Effects on crop growth, development, dry matter partitioning and kernel set. Crop Sci., (35): 1376-1383.

Willey, R.W. and M. Natarajan. 1980. Some aspects of resource use in sorghum/pigeon pea intercropping. Ind. J. Genet., (40 A): 16-26

Zamski, E. and A.A. Schaffer. 1996. Photoassimilate distribution in plants and crops. Source-Sink Relationship Macrel Dekker, INC.

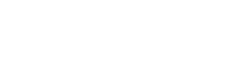

\section{تحمل ذرة الهل عل نرة الحبوب تهت مستوبلتمختلفة من النيتروجين ومواعيد الهش}

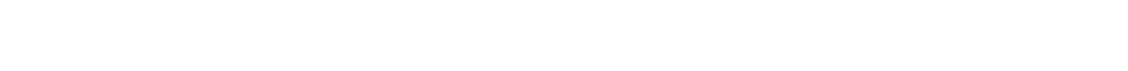

القديرات بلستخدل الذرة العلف عند عمر 0ع يومامن الزراعة)

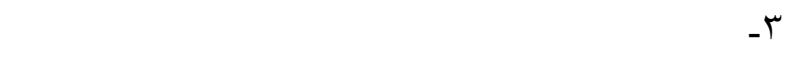

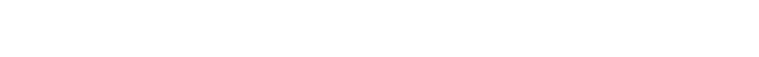

$$
\text { النيتروجن. }
$$

ع- زيادة مكافع المادة الجلفة الناتج هة ء ـن تحمي لـ ذرة

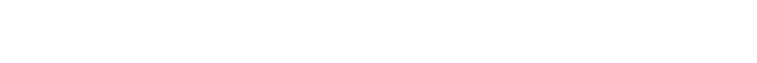

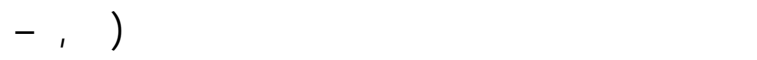

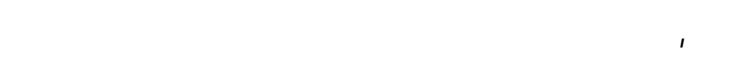

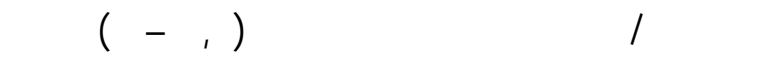

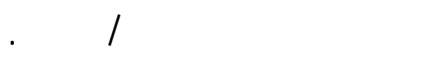

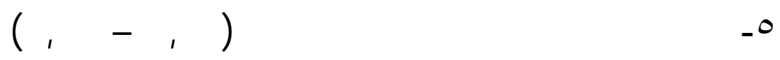

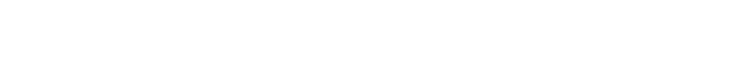

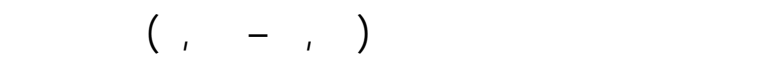

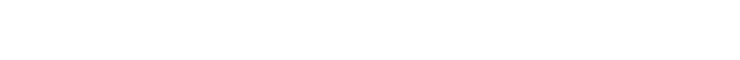

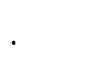

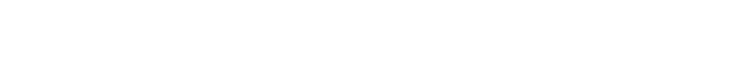

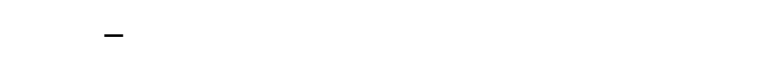

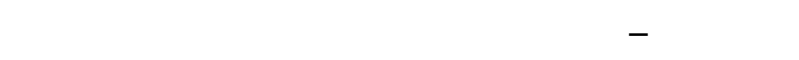

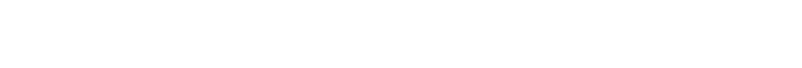

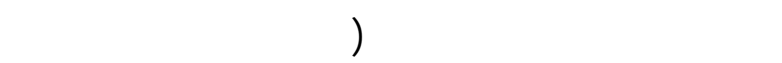

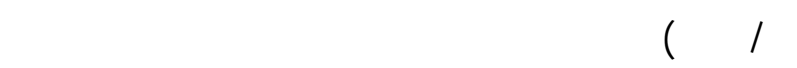

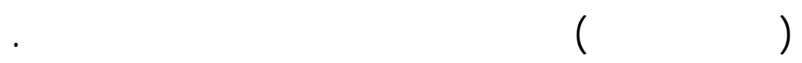
ويمكن اليجاز اهم النتائج المتحصل عليها فيما يلى:

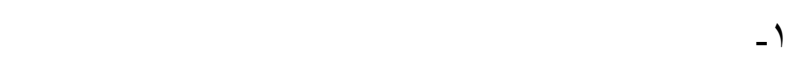

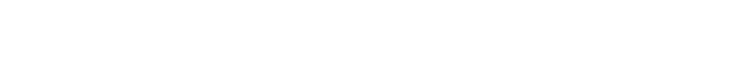
حبة ومحصول الحبوب للهكتار ودليل الحصاد وك ذذك ولك النكائ على المحصول الأخضر ونسبة المادة الجافة فيه.

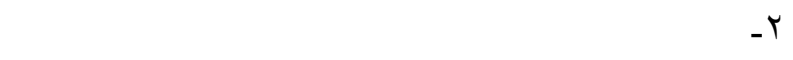

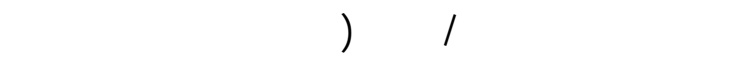

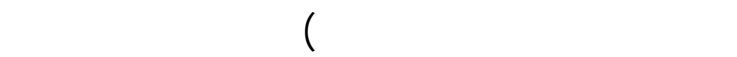

